\title{
Self Determined Plan to Reduce The Risk of Pesticide Tocixity in Karo
}

\author{
Sri Fajar Ayu ${ }^{1}$ \\ Department of Agribusiness, Faculty of Agriculture \\ Universitas Sumatera Utara \\ Medan, Indonesia \\ srifajar.ayu@gmail.com
}

\author{
Destanul Aulia ${ }^{2}$ \\ Faculty of Public Health \\ Universitas Sumatera Utara \\ Medan, Indonesia \\ destanul.aulia@usu.ac.id
}

\author{
Anisah Baharom ${ }^{3}$ \\ Department of Community Health \\ Faculty of Medicine and Health Science, University Putra Malaysia \\ Selangor, Malaysia \\ anisbaharom@yahoo.com
}

\begin{abstract}
Farmers in Desa Gajah, Simpang Empat Subdistrict, Karo, use pesticide to protect their crop from pests and diseases. Poor self-determined pland to reduce the risk of pesticide toxicity among farmers ruined the safe usage of the pesticide. This conditions warrants further research on the usage of personal protective equipment and the level of cholinesterase in the farmers' blood. These findings will assist in the development of a self-determined plan to reduce or minimize the risk of pesticide toxicity among the farmers. A total of 75 respondents were interviewed and their blood samples were taken. Almost all the respondents did not use complete personal protective equipment and majority have poor awareness of their health status. The results of the study also showed significant association between the farmers' selfmanagement to reduce pesticide toxicity which include partial or complete usage of personal protective equipment, and cholinesterase level in the blood. Positive correlation among the two shows that usage of complete personal protective equipment can protect the farmers from the risk of pesticide toxicity indicated by a reduction in cholinesterase level. To ensure the health of the farmers, the usage of complete personal protective equipment must be prioritized rather than having and using the pesticide. Therefore, farmers should practice safe self-detremined plan before using pesticide and be aware of the effect on their health status through the usage of complete personal protective equipment.
\end{abstract}

Keywords - Pesticide; Personal Protective Equipment; Cholinesterase; Self- determined plan

\section{INTRODUCTION}

Studies have shown that the use of pesticides can increase farm production [1], [2], [3], [4], [5]. Increased production will raise income received by farmers in every harvest activity. However, the use of pesticides does not always have a good impact, especially on the environment and the body of farmers. In large or small quantities, pesticides can trigger the poisoning of farmers' bodies. It is characterized by a decrease in blood cholinesterase levels. [6], [7], [8], [9]. Poisoning occurs due to pesticide contamination in the farmer's body. Pesticide contamination often occurs through the digestive system of the mouth. In addition, it also occurs through the respiratory system and excretion system (skin pores) [10], [11], [12]. As a result of pesticide contamination to the body, there is a risk of poisoning such as decreased productivity, loss of income due to loss of working time and expenditure for curative action, especially on acute poisoning [13], [14], [15].

Losses due to poisoning pesticides actually have received attention from public health observers. This is marked by the emergence of personal protective equipment (PPE) products. This equipment is expected to reduce the risk of poisoning to pesticide spraying farmers. However, horticulture farmers still rarely used all of this equipment. Good planning is required before applying pesticides to make this PPE available.

If realized further, farming activities is a production process. This process requires careful planning. Relying on work experience without considering the functions of management especially planning in production activities will have a negative impact.

Planning in farming activities begins with consideration of investment and production inputs to be used during the production process. The main investments in horticultural crops such as land, farm equipment and equipment, while important production inputs are seeds or seeds of plants, fertilizers and pesticides.

Farming is highly dependent on the use of production inputs such as pesticides. In fact, the use of pesticides is considered to provide guarantees on farm production. 
Pesticides can protect horticultural crops from pest attack. So that the resulting production can increase and look quality [16].

Planning in farming can be categorized 1) predetermined that is a farming plan arranged and determined by government, 2) self-determined plan that planning of farming, which arranged based on the self-desire, 3) joint plan is farming planning, which was composed by the cooperation of both [17].

Pesticide poisoning has a mild impact such as skin disease until death. In fact, after much counseling about the dangers of pesticide use, the farmers can plan themselves (self-determined plan) as desired and has become a need to keep himself from poisoning pesticides. This can be done by planning the use of PPE from the beginning. Based on this, this study would like analyzing the farmer self-determined plan in order to reduce the risk of pesticide poisoning.

\section{METHOD}

This study aims to examine the relationship between planning made by farmers in anticipating pesticide disorders through the use of personal protective equipment with their blood cholinesterase levels. The study was conducted in Gajah Village, Simpang Empat Sub-district, Karo. There are 75 respondents selected at random. The method of analysis used is descriptive method and Spearman's rho correlation analysis.

According to ref [18], Spearman's rho correlation is performed using SPSS 20 applications. Through SPSS obtained ouput, it can be seen the interpretation of the relationship between the variables studied. The criterion seen is the value of correlation coefficient $\left(r_{\mathrm{s}}\right)$ and Sig. (2tailed). The correlation coefficient shows the strength of the relationship between the two variables with the following criteria $\mathrm{r}_{\mathrm{s}}$ :

1. $\mathrm{r}_{\mathrm{s}} \cdot 00-.19$ "very weak"

2. $r_{\mathrm{s}} \cdot 20-.39$ "weak"

3. $r_{\mathrm{s}} \cdot 40-.59$ " moderate"

4. $\mathrm{r}_{\mathrm{s}} \cdot 60-.79$ " strong"

5. $\mathrm{r}_{\mathrm{s}} \cdot 80-1.0$ "very strong".

\section{RESULT AND DISCUSSION}

\section{Self Determined Plan}

The entry of pesticides into the body has a relationship with less self-protection. So that the path that can cause penetration of pesticides is susceptible to pesticides. The use of masks, for example, has a connection with pesticide poisoning. It is as stated that the use of masks has a relationship with pesticide poisoning in pest farmers. Personal protector is not perfectly able to inhibit poisoning, can only reduce the severity of pesticide poisoning [19].

At the time of spraying pesticides, pesticide solution granules are very easily carried by the wind. It is very susceptible to the entry of pesticide fluid into the body through the respiratory tract. To protect this respiratory tract, the pesticide sprayer should use a mask.

In general, personal protective equipment used by farmers in spraying pesticides is a mask and gloves. Mask aims to protect the contamination of pesticides by mouth and nose by air media. The gloves as a protective hand skin from the danger of entry of toxic materials.

The gloves used by pest sprayers are long-lasting gloves. The goal is to allow gloves to fit into the sleeves or in the sleeves. Another thing that can be used is trousers and shirts with long sleeves and glasses for the eyes protected from the dangers of pesticides [19].

The results of a study of self-determined plans to avoid pesticide poisoning demonstrated through the use of personal protective equipment are presented in Table 1. Not all respondents in the study used self-protective equipment in a complete amount. This incomplete usage is a reflection of poor planning. However, when referring to [11], the use of personal protective equipment on pesticide sprayers can be fully said when using at least five materials.

TABLE 1. PERSONAL PROTECTIVE EQUIPMENT BY RESPONDEN

\begin{tabular}{|l|l|c|c|}
\hline No & \multicolumn{1}{|c|}{$\begin{array}{c}\text { Personal Protective } \\
\text { Equipment }\end{array}$} & $\begin{array}{c}\text { Persentase of } \\
\text { User } \\
(\boldsymbol{\%})\end{array}$ & $\begin{array}{c}\text { Persentase } \\
\text { Not User } \\
(\boldsymbol{\%})\end{array}$ \\
\hline 1. & Mask & 32,0 & 68,0 \\
\hline 2. & Gloves & 2,7 & 97,3 \\
\hline 3. & Boots & 49,3 & 50,7 \\
\hline 4. & Long-sleeved Clothes & 92,0 & 8,0 \\
\hline 5. & Trousers & 93,3 & 6,7 \\
\hline 6. & Heat/Headgear & 0,0 & 20,0 \\
\hline 7. & Sun Glasses & \multicolumn{2}{|c|}{ Source: Primary Data, 2017 } \\
\hline
\end{tabular}

Referring to the study, only $10.7 \%$ of respondents used an incomplete protective device. The use of gloves and glasses is still very minimal among respondents, while boots used by almost half of the respondents. The results show that the number of respondents who use the mask is $32 \%$. The most widely used personal protective equipment of the respondents is a long-sleeved shirt, trousers and headgear. 
Glasses and gloves used are still lacking among respondents.

Lack of knowledge regarding the importance of PPE can be one reason behind the lack of use of personal protective equipment. The farmers should be aware of the use of this tool aims, that is to reduce health losses due to poisoning. Health is the initial capital for farmers in carrying out their farming activities [20].

The use of PPE has a connection to the farmer's knowledge of its benefit. Knowledge of personal protective equipment ultimately leads to adherence to its use. This is in accordance with the study [21] that the level of knowledge has a relationship with compliance in the use of personal protective equipment.

\section{Relationship between the Use of Personal Protective Equipment and Blood Cholinesterase Level}

Use of PPE is expected to protect the body of pesticide sprayers from poisoning due to pesticide contamination. However, most farmers have not been applied in a complete amount. This can be because they don't have all of them. As a result, the potential for poisoning can increase. Pesticide poisoning in the human body can be monitored by looking at blood cholinesterase levels. This is because cholinesterase is a substance that can be decreased due to the entry of active ingredients of pesticides into the human body.

The use of pesticides is also similar to the use of another equipment. User of pesticides should obey the pesticide user management procedures. As with any other product, the use of pesticides should be done with caution. Using proper clothing and personal protective equipment can help reduce the impact of pesticide exposure and reduce the risk of pesticide poisoning [22].

The lack of self-protective equipment by respondents is feared to have an impact on the high risk of poisoning for farmers. The result of correlation analysis presented in Table 2 shows that spearman's rho correlation value is 0.726 . This value indicates that there is a strong relationship between the two variables. Use of personal protective equipment has a positive effect on blood cholinesterase levels. This can be seen from the positive value shown in spearman's rho correlation coefficient. Respondents who used a complete self-protective device had higher blood cholinesterase levels. Meanwhile, when the use of personal protective equipment only slightly, it affects the low levels of Cholinesterase in the blood of respondents. The habit of using personal protective equipment in spraying pesticides has a relationship with the signs of poisoning to farmers. This habit also becomes the variable with the most dominant relationship to poisoning signs compared to the level of knowledge [23].

The significant value of 2-tailed on the result of correlation analysis is 0.000 . At the 0.01 significance level, it shows that there is a significant relationship between the use of personal protective equipment with the blood cholinesterase level of respondents. This result has a similar meaning to the study [19] which states that there is a relationship between the use of masks with pesticide poisoning in farmers. Ref. [22] also mentioned that the use of protective clothing and personal protective equipment when touching and spraying pesticides can reduce the risk of exposure to pesticides.

No matter how high the pesticide toxicity is used, if exposure risks can be minimized and prevented from the start, then the harm caused by pesticide poisoning will also be low. Therefore, personal protective equipment should be prepared by farmers from the start of farming. This preparation can be started by providing specific budgeting for the procurement of personal protective equipment and improving farmers 'knowledge about farmers' health urgency as well as optimizing the use of pesticides and other inputs.

TABLE 2. CORRELATIONS COEFFICIENT Correlations

\begin{tabular}{|c|c|c|c|c|}
\hline & & & Level of AChE & PPE \\
\hline \multirow{6}{*}{$\begin{array}{l}\text { Spearman's } \\
\text { rho }\end{array}$} & \multirow{4}{*}{$\begin{array}{l}\text { Level of } \\
\text { AChE }\end{array}$} & $\begin{array}{l}\text { Correlation } \\
\text { Coefficient }\end{array}$ & 1,000 &, $726^{* *}$ \\
\hline & & Sig. (2-tailed) & . & ,000 \\
\hline & & $\mathrm{N}$ & 75 & 75 \\
\hline & & $\begin{array}{l}\text { Correlation } \\
\text { Coefficient }\end{array}$ &, $726^{* *}$ & 1,000 \\
\hline & \multirow[t]{2}{*}{ PPE } & Sig. (2-tailed) & ,000 & . \\
\hline & & $\mathrm{N}$ & 75 & 75 \\
\hline
\end{tabular}

\section{CONCLUSION}

1. The results of the study indicate that $10.7 \%$ of respondents have not conducted a comprehensive selfset plan to reduce the risk of pesticide poisoning.

2. There is a significant relationship between the selfdetermined plans reflected by using PPE with cholinesterase blood of farmers.

\section{RECOMMENDATIONS}

1. It is suggested to the farmers to prioritize the procurement of personal protective equipment than the procurement 
and use of pesticides because pesticides should be used optimally.

2. Farmers should also implement self-determined plans when using pesticides and increase knowledge about the importance of using personal protective equipment.

3. To the stakeholders, it is suggested to do periodic cholinesterase checks in order to monitor and anticipate pesticide poisoning in farmers.

\section{ACKNOWLEDGEMENT}

The authors thank to Research Institute of Universitas Sumatra Utara for providing moral and material assistance in the implementation of this research and publication, also to the Ministry of Research Technology and Higher Education (Kemenristekdikti), which is also a funding for this study through scheme Penelitian Produk Terapan DRPM 2017.

\section{REFERENCES}

[1] Darmayanti, Lien, "Factors affecting production, income and employment in wetland paddy farm in irrigation area Parigi Moutong" Faktor-Faktor yang mempengaruhi produksi, pendapatan dan kesempatan kerja pada usahatani padi sawah di daerah irigasi Parigi Moutong", UNS: Semarang, SEPA Vol. 9 No. 2, Februari 2013, ISSN: 1829-9946, in press

[2] Suprayitno, "Factors affecting red chili farming income " "Faktor-faktor yang mempengaruhi pendapatan usahatani cabai merah", Universitas Bojonegoro: Bojonegoro, E-Journal Unigoro, 2015, in press

[3] Kalauw, Saddam H.S, Natelda, R. Timisela, M.T.F Tumuhury, "The analyze factors are influence the production in bean farming (Phaseolus vulgaris $l$ ) in telaga kodok hamlet central mollucas regency" "Analisis faktor-faktor yang mempengaruhi produksi sayuran buncis di Dusun Telaga Kodok Kabupaten Maluku Tengah", Universitas Pattimura: Maluku, Journal Agrilani Universitas Pattimura Volume 3 No. 2, Juni 2015, in press

[4] Sujana, Wulandari, "Analisis Pendapatan dan faktor produksi yang mempengaruhi usahatani tomat di Desa Lebak Mundung, Bandung" IPB: Bogor, Agribisnis FEM IPB, 2010, unpublished

[5] Hartati, Anny and Kabul S, "The Efficiency Level of Production Factors on Potato Farming in Sub District Karangrejo Purbalingga, Central Java", UNSOED: Purwokerto, Jurnal Agrin Volume 16 No. 1 April 2012, ISSN: 1410-0029, in press.

[6] Rustia, Hana N, Bambang Wispriyono, Dewi Susanna, Fitra N.L, "Lama pajanan Organoposfat terhadap penurunan aktivitas Enzim Kolinesterase dalam darah petani sayuran". UI: Jakarta, Makara Kesehatan Volume 14 No. 2 Desember 2010, in press.

[7] Rahmawati, Yeviana D dan Tri Martiana, "Effect of farmer characteristic factors and spraying methods on Cholinesterase levels" "Pengaruh faktor karakteristik petani dan metode penyemprotan terhadap kadar Kolinesterase", UNAIR: Surabaya, The Indonesian Journal of Occupational Safety, Health and Environment Vol. 1 No. 1 Januari-April 2014: 85-94, in press.

[8] Zulmi, Nizar, "Hubungan antara frekuensi dan lama penyemprotan dan interval kontak pestisida dengan aktivitas Cholinesterase petani di
Desa Kembang Kuning Kecamatan Cepogo" UMS: Surakarta, Published by Fakultas Ilmu Kesehatan UMS, 2016, in press.

[9] Raini, Mariana, "Toksikologi pestisida dan penanganan akibat keracunan pestisida", Media Litbang Kesehatan Volume 17 No. 3, 2007, in press.

[10] Utami, Desi P, Onny Setiani, Hanan L.D, Yusniar Hanani.D, "Association between exposure organophospate pesticides with Erythrocyte Sedimentation Rate (ESR) among farmers in Desa Sumberejo, Ngablak, Magelang" "Hubungan paparan pestisida organofosfat dengan laju endap darah (led) pada petani di Desa Sumberejo Kecamatan Ngablak Kabupaten Magelang", UNDIP: Semarang, e-Journal Kesehatan Masyarakat Volume 5 No. 3 Juli 2017, ISSN: 2356-3346, in press

[11] Kurniasih, Siti A, Onny Setiani, Sri Achadi N, "Factors related to pesticides exposure and Anemia on horticultural farmers in Gombong Village Belik Sub District Pemalang Central Java" "Faktor-faktor yang terkait paparan pestisida dan hubungannya dengan kejadian Anemia pada petani hortikultura di Desa Gombong Kecamatan Belik Kabupaten Pemalang Jawa Tengah”, UNDIP: Semarang, Jurnal Kesehatan Lingkungan Indonesia Vol. 12 No 2, Oktober 2013, in press.

[12] Pamungkas, Oktofa S, "Bahaya paparan pestisida terhadap kesehatan manusia", UNDIP: Semarang, portalgaruda.org, Bio Edukasi Volume XIV No. 1, April 2016, in press.

[13] Pimentel, David and Michael B, "Environmental and economics costs of the application of pesticides primarily in the United States", Springer.com: New York, Integrated Pest Management Volume 3, 2014 ISBN: 978-94-007-7795-8, in press

[14] Choi, Yeongchull et al, "Economic burden of acute pesticide poisoning in South Korea", Journal of Tropical Medicine and International Health Volume 17 No. 12, December 2012, pp. 15341543 , in press.

[15] Bourguet, Denis and Thomas G, "The hidden and external costs of pesticide use", Springer.com, Sustainable Agriculture Reviews, Volume 19 Issue 6, 2016 ISBN: 978-3-319-26776-0, in press

[16] M, Ameriana, "Farmer's behavior in using chemical pesticide on vegetable" "Perilaku petani sayuran dalam menggunakan pestisida kimia”, Journal Hortikultura Volume 18 No. 1, 2008 pp 95-106, in press.

[17] Suratiyah, K “Ilmu Usahatani”, Penebar Swadaya: Jakarta, 2009.

[18] http://www.statstutor.ac.uk/resources/uploaded/spearmans.pdf

[19] Kurniawan, Anggoro, “ The influence of using Self Protector Tools (APD) by pesticides poisonous incidentin farmers spreading plant disease in Ngrapah, Banyubiru, Semarang Regency 2008" "Hubungan antara penggunaan alat pelindung diri (APD) dengan kejadian keracunan pestisida pada petani penyemprot hama di desa Ngapah Kecamatan Banyubiru Kabupaten Semarang Tahun 2008". UNNES: Semarang, in press.

[20] Achmadi, Umar Fachmi, Manajemen kesehatan berbasis wilayah, Kompas: Jakarta, 2005.

[21] Darmayanti, I D.A.A.I, Ketut Tirtayasa, I Kadek Saputra, "Hubungan antara tingkat pengetahuan dengan kepatuhan dalam menggunakan alat pelindung diri pada petani pengguna pestisida". UNUD: Bali, COPING Ners Jurnal Vol. 3 No. 3 September-December 2015, ISSN: 23031298, 2015, in press.

[22] Clyde L. Ogg, et al, "Protective clothing and equipment for pesticide applicators" Institute of Agriculture and Natural Resources University of Nebraska: Nebraska, 2012, in press

[23] Sularti and Abi Muhlisin, "tingkat pengetahuan bahaya pestisida dan kebiasaan pemakaian alat pelindung diri dilihat dari munculnya tanda gejala keracunan pada kelompok tani di Karanganyar", FIK Universitas Muhammadiyah: Surabaya, 2012, in press. 